\title{
A century-scale, human-induced ecohydrological evolution of wetlands of two large river basins in Australia (Murray) and China (Yangtze)
}

\author{
Giri R. Kattel ${ }^{1,2,3}$, Xuhui Dong ${ }^{1,4}$, and Xiangdong Yang ${ }^{1}$ \\ ${ }^{1}$ Nanjing Institute of Geography and Limnology Chinese Academy of Sciences, 73 East Beijing Road, Nanjing 210008, China \\ ${ }^{2}$ Water Research Network, Faculty of Science and Technology, Federation University Australia, Mt. Helen, Ballarat, \\ Victoria 3350, Australia \\ ${ }^{3}$ Environmental Hydrology and Water Resources Group, Department of Infrastructure Engineering, the University of \\ Melbourne, Parkville, Melbourne, Victoria 3010, Australia \\ ${ }^{4}$ Aarhus Institute of Advanced Studies, Høegh-Guldbergs Gade 6B, 8000 Aarhus C, Denmark
}

Correspondence to: Giri R. Kattel (grkattel@ niglas.ac.cn)

Received: 24 June 2015 - Published in Hydrol. Earth Syst. Sci. Discuss.: 24 August 2015

Revised: 7 May 2016 - Accepted: 17 May 2016 - Published: 3 June 2016

\begin{abstract}
Recently, the provision of food and water resources of two of the world's largest river basins, the Murray and the Yangtze, has been significantly altered through widespread landscape modification. Long-term sedimentary archives, dating back for some centuries from wetlands of these river basins, reveal that rapid, basin-wide development has reduced the resilience of biological communities, resulting in considerable decline in ecosystem services, including water quality. Large-scale human disturbance to river systems, due to river regulation during the mid-20th century, has transformed the hydrology of rivers and wetlands, causing widespread modification of aquatic biological communities. Changes to cladoceran zooplankton (water fleas) were used to assess the historical hydrology and ecology of three Murray and Yangtze river wetlands over the past century. Subfossil assemblages of cladocerans retrieved from sediment cores $(94,45$, and $65 \mathrm{~cm})$ of three wetlands: Kings Billabong (Murray), Zhangdu, and Liangzi lakes (Yangtze), showed strong responses to hydrological changes in the river after the mid-20th century. In particular, river regulation caused by construction of dams and weirs together with river channel modifications, has led to significant hydrological alterations. These hydrological disturbances were either (1) a prolonged inundation of wetlands or (2) reduced river flow, both of which caused variability in wetland depth. Inevitably, these phenomena have subsequently transformed the natural wet-
\end{abstract}

land habitats, leading to a switch in cladoceran assemblages to species preferring poor water quality, and in some cases to eutrophication. The quantitative and qualitative decline of wetland water conditions is indicative of reduced ecosystem services, and requires effective restoration measures for both river basins which have been impacted by recent socioeconomic development and climate change.

\section{Introduction}

There has been a worldwide growing awareness of the value of healthy flow regimes (hydrology), as key "drivers" of the ecology of large rivers and the floodplain wetlands which attend them (Bedford, 1996; Puckridge et al., 1998; Richter et al., 2003). Natural flows maintain ecological processes which include valuable biodiversity in the ecosystems of river systems and their associated floodplain wetlands. The river channels connected to these floodplain wetlands discharge water, mixed with rich sources of carbon, energy, and nutrients from the river and its catchments, to the wetlands (Bunn and Arthington, 2002; Maddock et al., 2004). In addition, the allochthonous sources of organic matter deposited during flood pulses support reproduction and growth of biota (Junk et al., 1989; McGowan et al., 2011). Integration of local autochthonous production, including algae and inputs 
from the riparian zone during pulse events, further supports available energy for higher trophic levels (Thorp and Delong, 1994). As a result, large rivers and their associated floodplain wetlands are a potential source of ecosystem goods and services to humans, for example, flood attenuation, water purification, fisheries, and other foods, plus a range of marketable goods (Poff et al., 2003; Di Baldassarre et al., 2013).

However, the flow regime of large rivers has been consistently modified to meet continual demands of water for mono-agriculture and hydroelectricity (Nilsson and Berggren, 2000; Davis et al., 2015). Many floodplain wetlands have been transformed into a new regime as a result of either overallocation of water to offstream uses, or to other alterations to the natural flow regimes of large river systems (Walker, 1985). The construction of dams and dykes obstruct migration pathways for fish between the river channels and wetlands, and the newly built reservoirs trap waterborne sediment. The diversion of water may lead to historical channels becoming permanently or intermittently dry. Subsequent inundation of upstream riparian zones increases soil anoxia, often extinguishing entire plant and animal populations and altering the riparian environment. Furthermore, downstream hydrological and geomorphological alterations can reduce groundwater recharge, and modify the pattern of sediment exchange between rivers and wetlands (Nilsson and Berggren, 2000).

Whilst it is recognized that widespread human disturbances have currently caused variation in biological and species diversity in many floodplain wetlands worldwide (Zhang et al., 1999; Maddock et al., 2004), the response of biological diversity to these disturbances is variable. Some floodplain wetlands have a reduced diversity index following the disturbance, while in other wetlands, the disturbance has paradoxically led to an increased diversity index (Power et al., 1996). In either case, the nature of these disturbances over time and space have altered habitat stability, which affects species diversity and ecosystem functioning, and are now potentially threatening the historical identity of these wetlands (Dumbrell et al., 2008; Biswas and Malik, 2010).

Further, despite some adjustments to the change by the society (Di Baldassarre et al., 2013), the threats posed by widespread hydrological alterations to large rivers are often ignored or sidelined, with the demand for energy, irrigated food production, and industrial use for the projected growth of human population being given a higher priority (Power et al., 1996). It is important, therefore, that while water allocation plans are being formulated to provide greater water security for immediate community use, it will be essential that understanding of the considerable socioeconomic benefits provided by healthy floodplain wetland ecosystems associated with these large rivers are not lost, and that degraded ecosystems are restored for the benefit of future generations (Poff et al., 2003). Key socioeconomic benefits, such as water purification, flood abatement, and carbon sequestration, all of which are maintained by wetland biodiversity and ecosystem functioning, will thus not be impaired if care is given to the wetlands of large river basins to ensure that they are not lost or degraded (Zedler and Kercher, 2005).

Recent evidence suggests that a significant proportion of the national economy of Australia and China has been generated by two of their large river systems, the Murray and the Yangtze rivers, respectively. These rivers have contributed to a range of ecosystem services, including food, mineral, and water resources, to the communities living in the river basins (Palmer et al., 2008; Zhang et al., 2015). However, because water has been abstracted heavily for irrigation, hydroelectricity, and industrial development in both river basins, there has been widespread disruption in the hydrology of the rivers, which includes the frequency, timing, and volume of flow in the main river and associated river channels linking to adjacent floodplain wetlands (Walker et al., 1995). This varying of natural flow regimes has interrupted natural flood pulses, leading to changes in hydraulic residence time, wetland depth, nutrient inputs, and sediment cycling in addition to changing the structure, function, and species diversity of downstream floodplain ecosystems (Power et al., 1996; Kingsford, 2000; Chen et al., 2011; Kattel et al., 2015).

There are some parallels in the historical experience of these two river systems, which makes this simultaneous study most appropriate. Records show that following the arrival of Europeans in Australia in the early 1900s, the River Murray system began to be regulated for irrigation, hydroelectricity, and navigation (Walker, 1985). The wetlands connected to the river were either inundated as water storage basins, or dehydrated due to upstream water extraction or diversion of connecting channels. Deforestation of the catchment became widespread during the expansion of agriculture. As a result, the majority of wetlands have been subjected to significant bank erosion and sedimentation (Gell et al., 2009). In China, similar contemporary pressure has been placed on the Yangtze River system, where similar largescale modifications of rivers and wetlands occurred during the 1950s-1970s. Riparian floodplain and wetland habitats across the Yangtze River basin were extensively reclaimed for agriculture and rural development by the construction of dykes. This resulted in a significant loss of vegetation in the upper reaches of the Yangtze, followed by soil erosion and siltation of downstream wetlands (Yin and $\mathrm{Li}, 2001$ ). The river sediment load of the Yangtze River between the 1960s and 1970s alone was more than $450 \mathrm{Mtyr}^{-1}$ (Yang et al., 2011a, b). Consequently, many lakes experienced reduced flood retention capacity due to disconnection from the main channel of the Yangtze River by construction of embankments and sluice gates in the river channels, which was subsequently followed by widespread eutrophication (Yu et al., 2009; Zhang et al., 2012). Because of alterations in natural flood pulses, ephemeral and temporary lakes tended to have fewer taxa than semipermanent channels or terminal lake habitats (Sheldon et al., 2002). In addition, excessive water abstraction or river-flow regulation in the Yangtze River 
disrupted natural variability in connectivity and hydrological regimes, consequently threatening ecological integrity, including the biodiversity of the floodplain system (Sheldon et al., 2002; Yang et al., 2006).

Studies show that the Murray and Yangtze river wetlands have lost significant density of submerged littoral macrophytes over the past century (Reid et al., 2007; Yang et al., 2008). For example, the subfossil assemblages of diatoms and cladocerans in the floodplain wetlands of the midreaches of the River Murray indicate a collapse of submerged vegetation coincident with the first appearance of the introduced conifer, Pinus radiata (Reid et al., 2007). Similarly, the multiproxy responses, including diatoms and physicochemistry of sediment of the Taibai Lake (lower Yangtze), show that after the 1990s, the lake shifted to hypereutrophic condition. This was thought to be due to increased dominance of algal biomass and a reduced density of submerged macrophytes (Liu et al., 2012). There has been a characteristic state shift in wetlands of both river systems due to the changes in the dynamics of submerged vegetation (Reid et al., 2007; Yang et al., 2008). The submerged vegetation in wetlands reduces phytoplankton by shading the substrate and competing for underwater light sources needed for photosynthesis, consequently improving the water quality by stabilizing sediment resuspension (Jeppesen and Sammalkorpi, 2002; Folke et al., 2004). However, the characteristic alternative stable states of ecosystems, which are thought to be buffered by naturally occurring hydrology, nutrient enrichments and submerged vegetation dynamics in large river floodplain wetlands, (e.g., Scheffer et al., 1993) have been substantially disrupted in recent decades. Today, the prior, undisturbed ecological state of the Murray and Yangtze river wetlands has been difficult to understand, due to the effects of multiple stressors, including human disturbances and climate change. For instance, following river regulation (1950s), the wetlands of Yangtze have become eutrophic, even in the presence of submerged vegetation (Qin et al., 2009).

Understanding the effects of disruption in natural hydrological regimes of the Murray and Yangtze rivers on diversity and community structure of consumers, such as cladoceran zooplankton (water fleas) in the adjacent floodplain wetlands, is crucial to assessing wetland ecosystem health. Both Australia and China have faced increasing challenges in addressing shortages of water and food supplies, resulting from reduced water flows in these catchments. A long-term monitoring of wetlands exposed to hydrological disturbance is important to ensure maintenance of ecosystem services, by identifying the causes of degradation and using effective and adaptive restoration measures.

The subfossil cladocerans have responded to past climate change, eutrophication, and water pollution in many shallow lakes (Jeppesen et al., 2001). Some cladocerans are also significant indicators of locally associated hydrological factors, including the river flow, lake water depth, sediment properties, macrophyte cover, and biotic interactions (Nevalainen,
2011). Recently, Pawlowski et al. (2015) have documented cladoceran-inferred palaeohydrology, including the formation of meandering channels, hydraulic characteristics, and water level change in the oxbow lake of the Grabia River (central Poland) during the late Glacial and Holocene periods. Whereas the role of fossil cladocerans is becoming increasingly significant for understanding the past hydrology of large river basins elsewhere, understanding cladoceran response to long-term hydrology and water level change of wetlands (ecohydrology) in the Murray and Yangtze rivers currently is limited. In this paper, we aim to examine three sites: the Murray and Yangtze river floodplain wetlands, Kings Billabong (Murray), and the Zhangdu and Liangzi lakes (Yangtze), each of which have been exposed to largescale human-induced hydrological disturbances during the 20th century as inferred by subfossil assemblage and diversity of cladocerans, and to discuss associated measures needed for water resource management.

\section{Study areas}

\subsection{Kings Billabong (River Murray)}

Kings Billabong $\left(34^{\circ} 14^{\prime} \mathrm{S}\right.$ and $\left.142^{\circ} 13^{\prime} \mathrm{E}\right)$ is a shallow $(\sim 1.8 \mathrm{~m}$ deep) wetland ( $210 \mathrm{ha})$, located along the River Murray near Mildura (northwest Victoria), Australia (Fig. 1a), and was once an important source of food and water for the Nyeri Nyeri aboriginal community. The intensification of agriculture around Kings Billabong by early European settlers began in 1891 and continued until 1923. Initially in 1896, Kings Billabong was used as a pumping station and was converted to a water storage basin (Lloyd, 2012). Modification of the landscapes around the billabong and construction of dams, including the series of locks and weirs for upstream water storages, have significantly altered the natural flow regime of the River Murray which feeds Kings Billabong (Gippel and Blackham, 2002). The hydrology and, in particular, the variability of flows which include duration and water retention time in the river, have substantially influenced the volume of water in Kings Billabong (Lloyd, 2012). Since formal regulation of the River Murray began in 1927, with construction of Lock 11 at Mildura and Lock 15 at Euston in 1937, downstream river flows and naturally occurring flood pulses have altered in many wetlands, including Kings Billabong (Gippel and Blackham, 2002). The artificial flooding linking Kings Billabong to the weir pool of Lock 11 has led to this wetland becoming permanently inundated.

The first sign of ecological impact due to river regulation on Kings Billabong was observed as a widespread dieback of river red gum (RRG) forests and the establishment of fringing cumbungi (Typha sp.) vegetation (Parks Victoria, 2008). Logging of RRG forests was intensified in the region until the 1950s, with the timber used to fuel steam-operated pumps and paddleboats along the river (Parks Victoria, 2008). The 
(a) River Murray (Kings Billabong), Australia

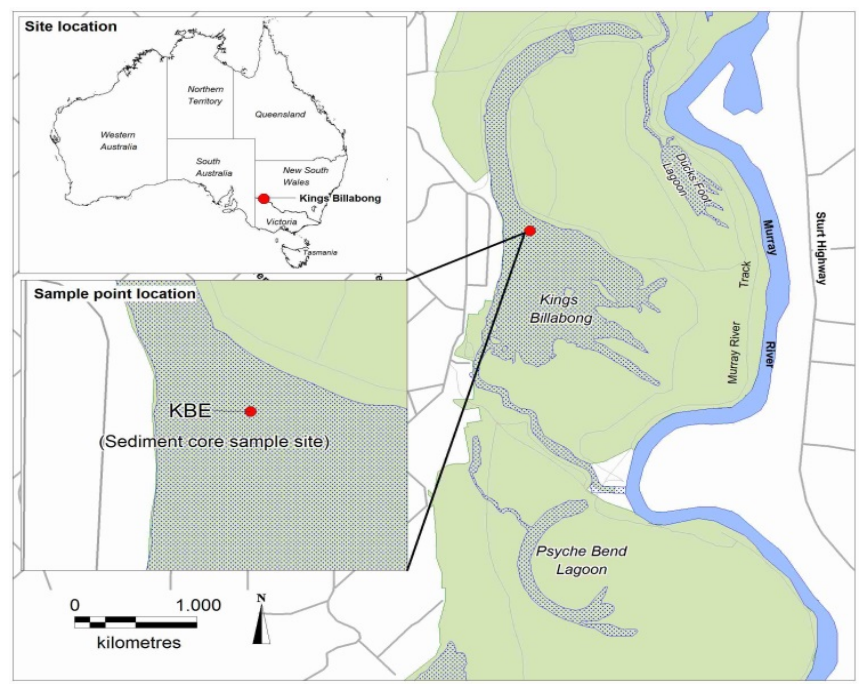

(b) Yangtze River (Zhangdu and Liangzi Lakes), China

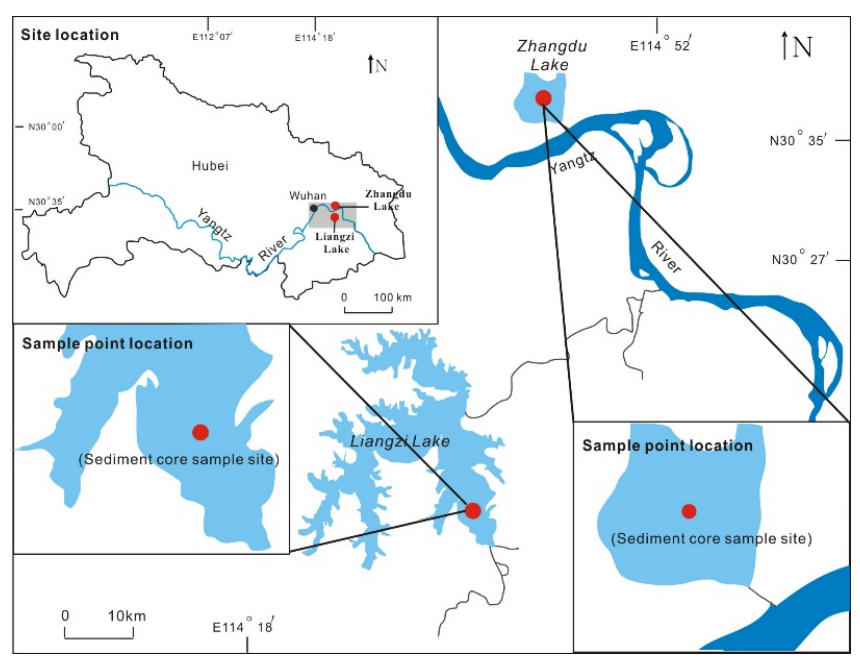

Figure 1. Study areas in Australia and China. (a) Kings Billabong, one of the wetland complexes of the River Murray system in southeast Australia and (b) Zhangdu and Liangzi lake wetland complex around the middle reaches of the Yangtze River in the Hubei Province of China. The red dots are coring locations for this study.

life cycle of native aquatic biota in the wetlands around the lower Murray has thus become disrupted due to the variation in natural wet-dry events caused by river regulation (Ellis and Meredith, 2005). Increased distribution range of exotic fish and weeds were also observed following regulation. For example, in a survey of native and exotic fish in Kings Billabong, Gambusia (an exotic species), comprised $35 \%$ of the total species collected (Ellis and Meredith, 2005).

Apart from human activity, climate change has also impacted the condition of Kings Billabong. Average water temperatures in southeast Australia have risen over the past 60 years and there has been a decrease of $40 \%$ in the total rainfall in the region (Cai and Cowan, 2008). This regional variability in climate change has led to significant changes in river flow, wetland volume, thermal structure, and alteration of catchment inputs, all of which are influenced by a marked increase in frequency and intensity of extreme events such as droughts and floods (Lake et al., 2000).

\subsection{Zhangdu Lake (Yangtze River)}

Zhangdu Lake $\left(30^{\circ} 39^{\prime} \mathrm{N}\right.$ and $\left.114^{\circ} 42^{\prime} \mathrm{E}\right)$ is a floodplain wetland (1.2 m deep) of the Yangtze River system, which is located in the Hubei Province, central China (Fig. 1b). During high river flows, Zhangdu Lake previously received flood pulses from the Yangtze River, however the lake was disconnected from the Yangtze River in the 1950s, due to the construction of dams and widespread land reclamation across the catchment. By the 1980s, the shoreline of Zhangdu Lake had been significantly modified as a result of the increased reclamation activity and construction of water conservancy infrastructure, which commenced in the 1970s. In 2005, af- ter the reclamation of $50 \mathrm{~km}^{2}$ of shoreline, funding from the World Wide Fund for Nature (WWF) enabled Zhangdu Lake to be seasonally reconnected with Yangtze River for the purpose of habitat restoration. This lake now has an area of $35.2 \mathrm{~km}^{2}$, with an average depth of $1.2 \mathrm{~m}$ and a maximum depth of $2.3 \mathrm{~m}$. The watershed lies within the northern subtropical monsoon zone, with a mean annual temperature of $16.3^{\circ}$, a mean annual rainfall of $1150 \mathrm{~mm}$, and evaporation of $1525.4 \mathrm{~mm}$. The terrain slopes gently with an elevation of 16-21 m. The main inflows of Zhangdu Lake are from the Daoshui River in the west and the Jushui River in the east. Water drains from the lake into the Yangtze River via an artificial channel in the southeastern corner. Historically, Zhangdu Lake has interacted not only with the Yangtze River when the water level is high but it has also connected with surrounding lakes, Qi Lake and Tao Lake, during flood events (Zhang et al., 2013). However, due to the construction of dams, dykes, and land reclamation, it became disconnected from the river in the 1950s. Water conservancy and reclamation construction reached a peak in the 1970s, attaining its current finished and formed shape during the 1980s. Following the mid-20th century reclamation phase, the rate of carbon accumulation in Zhangdu Lake has increased, possibly due to an increase in shallow marginal areas favoring the growth of carbon rich macrophytes (Dong et al., 2012). However, the ecological impacts of disconnection from the river in Zhangdu Lake have become severe. Wild fishery production has reduced from $95 \%$ in 1949 to less than $5 \%$ in 2002 , and fish diversity has decreased, from 80 species in the 1950 s to 52 species at present (Wang et al., 2005). To 
address this decline, funding from the WWF in 2005 reconnected Zhangdu Lake with the Yangtze River.

\subsection{Liangzi Lake (Yangtze River)}

Liangzi Lake $\left(30^{\circ} 3^{\prime} \mathrm{N}, 114^{\circ} 26^{\prime} \mathrm{E}\right)$ is a shallow wetland (3$5 \mathrm{~m}$ deep), located in the southeast region of the Hubei Province on the southern bank of the middle reaches of the Yangtze River. The lake area is $304.3 \mathrm{~km}^{2}$ with a drainage area of $3265 \mathrm{~km}^{2}$. The lake has an elevation of $20 \mathrm{~m}$ and is $31.7 \mathrm{~km}$ in length with a mean width of $9.6 \mathrm{~km}$ (Fig. 1b). The lake connects to Yangtze River via a $43.3 \mathrm{~km}$ river canal (Xie et al., 2001). Since 1992, the western part of the lake, approximately 6000 ha in area with a mean depth of $4.2 \mathrm{~m}$, has been separated from the main lake by a $2000 \mathrm{~m}$ nylon screen (mesh size $20 \mathrm{~mm}$ ) for the purpose of aquaculture. Water exchange occurs easily between the two parts of the lake. Intensive stocking with commercial fish, including grass carp Ctenopharyngodon idella (Val.), bighead carp Aristichthys nobilis (Richardson), and silver carp Hypopthalmichthys molitrix (Cuvier and Valenciennes), is common in the western part of the Liangzi Lake (Xie et al., 2001). Because of grass carp stocking, macrophytes were completely eliminated from the western part of the lake. However, areas of less intensive aquaculture still maintain an abundant density of submersed macrophytes, with Potamogeton maackianus (A. Bennet) as the dominant species (Xie et al., 2001). Apart from fisheries, Liangzi Lake provides significant services for drinking water, irrigation, transportation, and recreation to the people living around the four large cities, Wuhan, Huangshi, Ezhou, and Xianning Liangzi. Recently, one of the largest foreign investment projects to date in central and southern China, the Hubei Liangzi Lake International Golf Club, has opened a training center at the edge of the lake.

\subsection{Hydrological contexts of the Murray and Yangtze river wetlands}

Figure 3 presents hydrological contexts for both Murray and Yangtze river systems. This diagram shows the deviation of baseline flows of the two rivers and associated wetlands before and after regulation. Construction of weirs in the lower River Murray during the 1920s and 1930s, and construction of dams in the Yangtze River from the 1950s to the 1970s, significantly altered peak flows and downstream wetland hydrology (Lloyd, 2012; Yang et al., 2011a, b).

Naturally occurring spring flood patterns in the River Murray, experienced prior to the construction of Lock 11 in 1927, have been altered by regulation, and as a result, the amount of water released to meet peak irrigation demands has changed (Lloyd, 2012). Increased demand for water has resulted in the flow of the lower River Murray falling below the historical baseline (Fig. 2a-i). Regulation for wetland permanency has led to the depth of Kings Billabong being above the historical baseline level (Fig. 2a-ii).

In Zhangdu Lake, water levels were maintained through inflows from two rivers, the Daoshui River from the west and the Jushui River from the east, and outflow to the Yangtze River via by an artificial channel from the southeast corner of the lake. The water level was maintained by permanent connectivity between the Zhangdu Lake and the Yangtze River channels prior to the 1950 s, but became disrupted by regulation (Fig. 2b-i). The decline in annual discharge of the Yangtze River $(-11 \%)$ after the 1950s (Yang et al., 2011a, b), has led to a reduction of the historical baseline flow of the river, subsequently reducing the baseline water level in Zhangdu Lake (Fig. 2b-ii). The South-to-North Water Diversion Project, in addition to wetland reclamation and construction of new dams, particularly after the 1970s-1980s, has further altered the hydrology of Zhangdu Lake (Qin et al., 2009; Yang et al., 2010). However, the project initiated in 2005 by the WWF has recharged the channel hydrology and increased the water level of Zhangdu Lake (Fig. 2b-ii).

\section{Methods}

\subsection{Ecohydrological assessment of Murray and Yangtze river wetlands}

Questions related to evolution of ecohydrology of the wetlands of large river basins of Australia and China are rarely addressed. The observed monitoring data available for ecology and hydrology are often short and sketchy, and may not be reliable guides in reconstructing the contiguous centuryscale variability. However, the biological communities such as phytoplankton and zooplankton respond very well to flow regimes, habitat and channel modifications, and nutritional inputs during the flood events (Van den et al., 1994). The subfossil records of biota such as cladoceran zooplankton, and chemicals such as stable isotopes of carbon and nitrogen archived in wetland sediment, have the potential to indicate past ecological and hydrological changes of the floodplain environments. For example, the growth of small size littoral cladocerans (Alona sp.) can flourish at low flood frequency environments, which, together with the increased growth of telmatic plants, can provide crucial information regarding the past hydrological and ecological conditions of the riverine wetlands (Pawlowski et al., 2015).

In order to understand the changes in past hydrological conditions of wetlands associated with large rivers, the diversity and ecological conditions of the three floodplain wetlands, Kings Billabong, Zhangdu Lake, and Liangzi Lake, were assessed using subfossil cladoceran zooplankton remains retrieved from lake sediments deposited over the past century. A high-resolution subsampling of a $94 \mathrm{~cm}$ long core, collected from Kings Billabong, was carried out at $1 \mathrm{~cm}$ intervals. 
(a)-i. River Murray
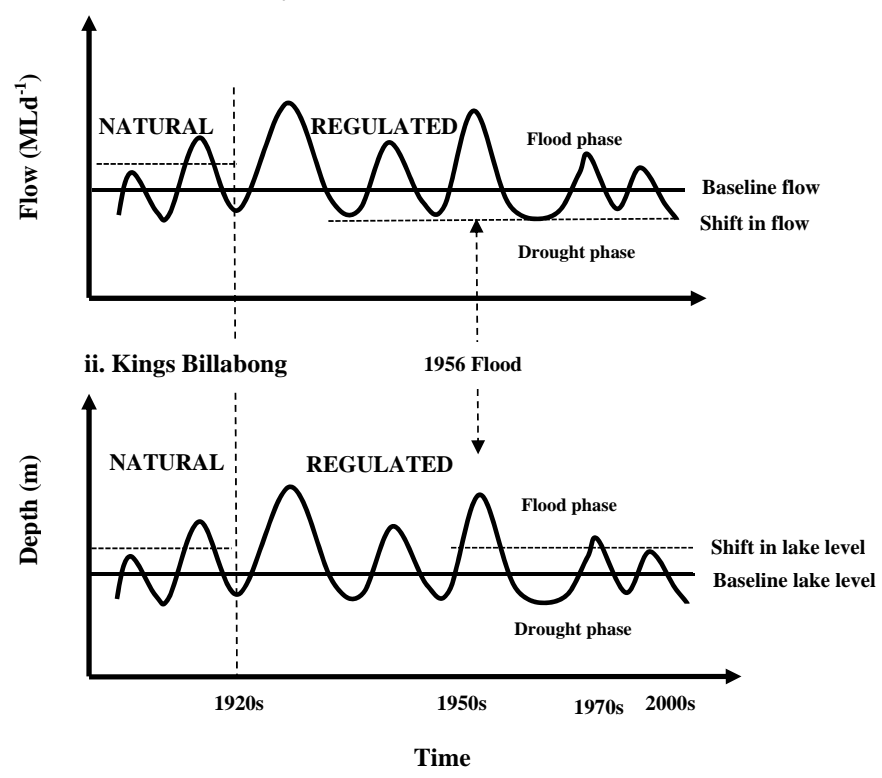

(b)-i. Yangtze River

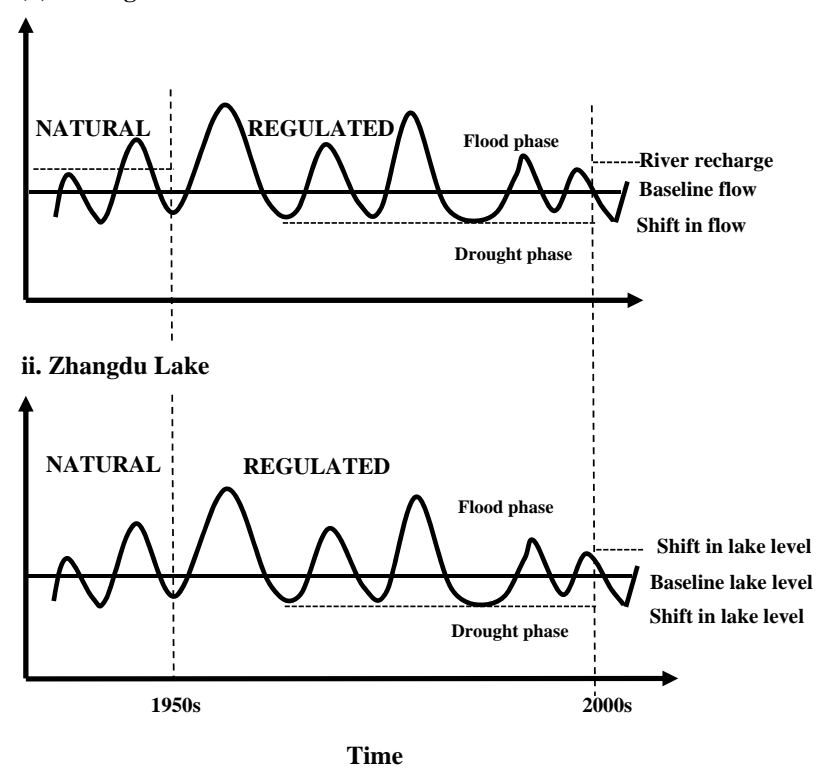

Figure 2. Hydrological contexts of the Murray and Yangtze rivers. River Murray: regulation was imposed by humans in the 1920s which resulted in low water volume in the downstream river channels, but Kings Billabong's conversion to a water storage tank permanently led to higher lake level, subsequently ceased natural dry-wet cycles; (a-i) and (a-ii) (left panel). Yangtze River: the first large-scale human impact on the river was imposed during the ca. 1950s, which ceased naturally occurring flood pulses in adjacent wetlands leading to a drying up of the river channel connecting to wetlands including low water volume in Zhangdu Lake; (b-i) and (b-ii) (right panel).

In the case of Zhangdu Lake, a subsampling of a $45 \mathrm{~cm}$ long core was carried out at $1 \mathrm{~cm}$ intervals for up to $27 \mathrm{~cm}$, and at $2 \mathrm{~cm}$ intervals for up to $45 \mathrm{~cm}$, respectively. For Liangzi Lake, the subsampling of a $65 \mathrm{~cm}$ core was carried out at $2 \mathrm{~cm}$ intervals. Subsamples from all three lakes, weighing approximately $3-4 \mathrm{~g}$ each as wet sediment, were treated with $100 \mathrm{~mL}$ of $10 \% \mathrm{KOH}$ solution, and heated at $60^{\circ} \mathrm{C}$ on a hotplate for at least $45 \mathrm{~min}$. Sieving of the subsample mixture was carried out through a $38 \mu \mathrm{m}$ mesh. More than 200 identifiable cladoceran remains were enumerated at $400 \times$ magnification from each subsample. Numbers were converted to individuals per gram dry weight $\left(\mathrm{gDW}^{-1}\right)$ of sediment, followed by the calculation of relative proportion of the remains present in the sample (Kattel et al., 2008). Cladoceran taxa were identified following the procedures suggested by Frey (1986), Shiel and Dickson (1995), Zhu et al. (2005) and Szeroczyńska and Sarmaja-Korjonen (2007).

\subsection{Dating}

The age chronology was based on the standard ${ }^{210} \mathrm{~Pb}$ dating for all sites (Appleby, 2001). For Kings Billabong, radionuclide activity was detected at $51 \mathrm{~cm}$, while the radionuclide activities for the Zhangdu and Liangzi lakes were detected at 45 and $65 \mathrm{~cm}$, respectively. The age modeling of Kings Billabong can be found in detail in Kattel et al. (2015).

The sediment samples from the Zhangdu and Liangzi lakes were dated using ${ }^{210} \mathrm{~Pb}$ and ${ }^{137} \mathrm{Cs}$ levels by nondestructive gamma spectrometry laboratory at the State Key Laboratory of Lake Science and Environment, NIGLAS. The activities of ${ }^{210} \mathrm{~Pb},{ }^{226} \mathrm{Ra}$ and ${ }^{137} \mathrm{Cs}$ in samples were determined by counting with an Ortec HPGe GWL series well-type coaxial low background intrinsic germanium detector. The ${ }^{137} \mathrm{Cs}$ was used to identify the peak that indicated use of the 1963 nuclear bomb. This evidence was then used for developing a constant rate of supply (CRS) model to calculate ${ }^{210} \mathrm{~Pb}$ chronology for the core. The important dates relevant to hydrological changes were indicated in the stratigraphy.

\subsection{Numerical analyses}

Hill's N2 diversity index was calculated for wetlands of both river systems to test the changes in species diversity of cladoceran counts over time. This diversity index assumes that the number of species in an ecosystem is uniformly distributed (Hill, 1973).

For subfossil cladoceran assemblage samples, dendrograms were produced in the Tilia*Graph following the constrained incremental sums of squares (CONISS) analysis. Zonation of samples in the diagram was based on the chord-distance dissimilarity coefficients obtained in CONISS (Grimm, 1987). Indirect ordination techniques, such as detrended correspondence analysis (DCA) were used for identifying species alignments with samples over time (Hill and Gauch, 1980). DCA was run for subfossil cladoceran samples meeting 200 counts in each sample followed 


\section{Wetland response to water quality change in Kings Billabong}

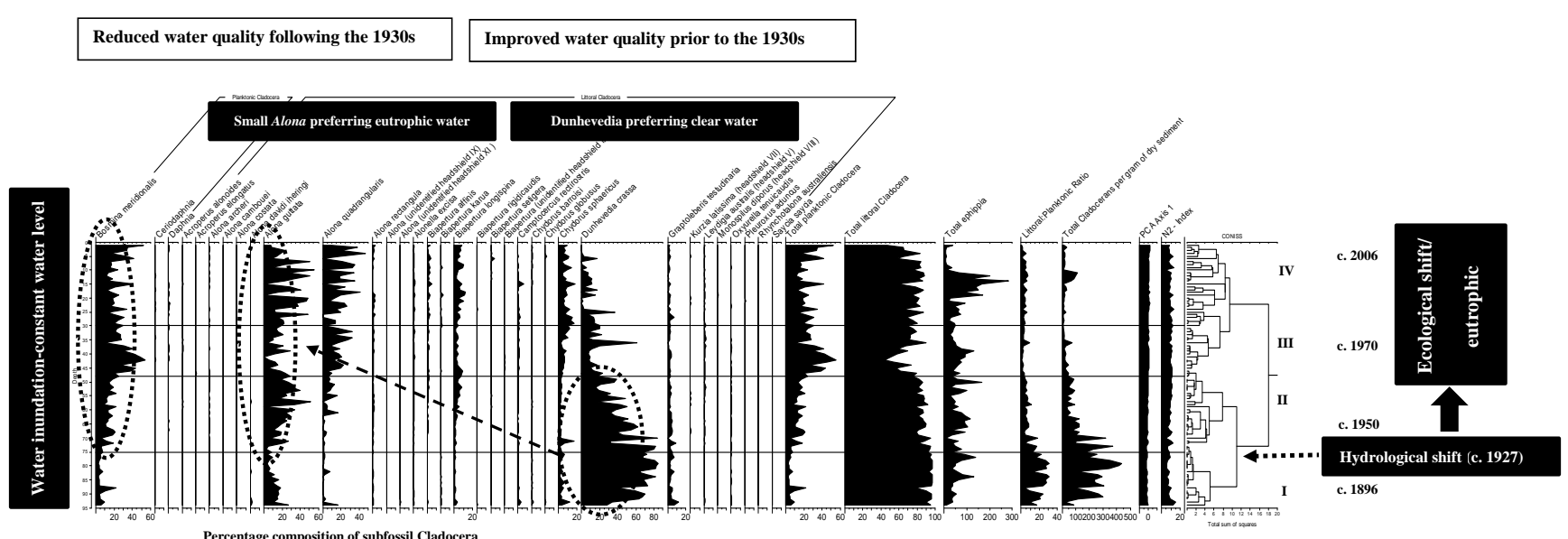

Figure 3. Percentage composition and N2 diversity index of subfossil cladocerans in Kings Billabong, their response to past hydrological and water quality change.

\section{Wetland response to water quality change in Zhangdu Lake}

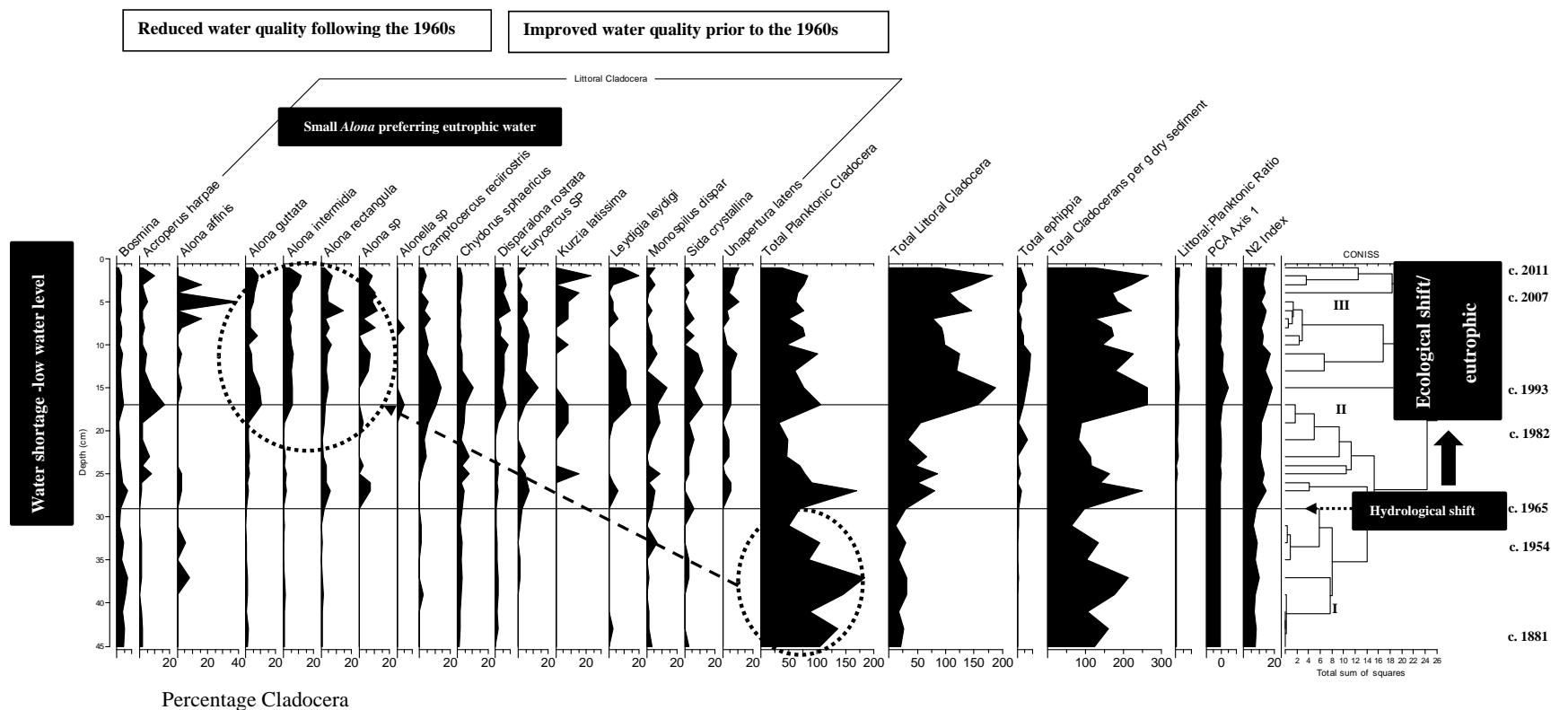

Figure 4. Composition (\%) and N2 index of subfossil cladocerans in Zhangdu Lake, and their response to past hydrological and water quality change.

by running correspondence analysis (CA) or principal components analysis (PCA) as per the gradient length of the first DCA axis (ter Braak, 1995). The CA and PCA sample scores were incorporated in the stratigraphy diagrams.

\section{Results}

The species richness (species count) and assemblages of subfossil cladocerans were assessed in wetlands of both river basins as these biological components are potential indicators for the past environmental conditions including the changes in ecology and hydrology of floodplain wetlands of Murray and Yangtze river basins. 


\subsection{Kings Billabong}

More than 40 species of subfossil cladocerans were recorded within Kings Billabong. The most commonly recorded cladoceran taxa were Bosmina meridionalis, Chydorus sphaericus, Biapertura setigera, Dunhevedia crassa, Biapertura affinis, and Alona guttata (Fig. 3). The diversity of these cladocerans in Kings Billabong, as revealed by the N2 diversity index, was responsive to past hydrology and water level changes. The N2 index was low during the 1900s, however, prior to human disturbance of the river during the 1870 s, as well as in the 1960s, the N2 diversity index was relatively high (Fig. 4).

The zonation of the assemblage structure of the subfossil cladocerans as well as the trend in littoral to planktonic ratios ( $\mathrm{L}: \mathrm{P}$ ratios) were potentially significant to infer the period of the ecohydrologic change including quantity and quality of water in Kings Billabong (Fig. 3). The subfossil assemblage of cladocerans in Kings Billabong showed four distinct changes in ecosystem. Until the 1890s, (Zone I) littoral cladocerans such as Dunhevedia crassa, Alona guttata, Chydorus sphaericus, and Graptoleberis testudinaria were the dominant species flourishing mostly in good water quality condition (Fig. 3). This period experienced a relatively low abundance of the planktonic species Bosmina meridionalis (Fig. 3). However, total littoral cladocerans gradually declined, while small littoral species, such as Alona guttata, became abundant during the period 1890-1950 (Zone II). During this time, the water quality began to decline, corresponding to an increasing density of planktonic $B$. meridionalis contributing to the total planktonic cladocerans. Some Daphnia records (1950s-1970s) were also retrieved, and coincided with a hydrological disruption, in the form of the 1956 flood, in the River Murray (Zone III) (Fig. 3). Although total littoral cladocerans declined, some littoral species such as Alona guttata and A. quadrangularis were still abundant during this time. However, in the 1970s-2000s, conditions of wetlands declined corresponding to increased planktonic $B$. meridionalis and littoral A. guttata, Biapertura longispina, A. quadrangularis, and Chydorus sphaericus, while the littoral $D$. crassa declined significantly. In the meantime, the frequency and density of cladoceran resting eggs also increased in the sediment (Fig. 3).

In Kings Billabong, a major hydrological shift occurred in 1927 leading to significant hydrologic dynamics of wetland including the volume of water (Fig. 3). The L:P ratios of cladocerans indicated a major hydrological change of the wetland when they began to decline rapidly from about $75 \mathrm{~cm}$ depth (ca. 1930s) (Fig. 3). The subfossil assemblages of littoral and planktonic cladocerans over a longer timescale responded to these hydrological changes of the River Murray, together with subsequent changes of water level of Kings Billabong. The construction of Lock 11 in the River Murray near Mildura led to permanent inundation of Kings Billabong during the 1920s-1930s, the time of major hydrological shift
(Fig. 3). Because of the expansion of the pelagic habitat as a result of the increased amount of water in Kings Billabong, the assemblage of subfossil Bosmina was retrieved high in the sediment (Fig. 3). Although the billabong was inundated and hydrologically stable with constant water depth, there was sustained increase in the abundance of some littoral cladocerans including Alona guttata, Alona quadrangularis, and Biapertura longispina. Following this hydrological shift, Kings Billabong began to respond to the change with declining water quality. For example, littoral cladocerans such as $A$. guttata and $A$. quadrangularis, which prefer poor water conditions, were sustained together with $B$. meridionalis. However, the assemblage of the dominant littoral cladoceran, Dunhevedia crassa, which prefers clean water conditions, significantly declined following the hydrological shift, from pre-regulated, variable water levels to post-regulated environment in Kings Billabong as a result of the sudden imposition of river regulation in 1927 (Fig. 3).

\subsection{Zhangdu Lake}

From the Zhangdu Lake, more than 36 cladoceran species were recorded, with Bosmina, Chydorus sphaericus, and Sida crystallina being the most commonly recorded taxa (Fig. 4). Other cladoceran species such as small Alona sp. (A. guttata and A. rectangula), also became increasingly responsive to past hydrological disturbances. These hydrological disturbances were also inferred by the $\mathrm{N} 2$ diversity index of cladocerans with representation of the species indicating increased disturbances. Whilst prior to the construction of the dam (ca. 1881-1954) the N2 index was low compared to the post-dam construction period, during the postdisturbance period, the levels of taxa preferring a disturbed environment increased (Fig. 4).

Three distinct hydrologic and ecosystem changes were observed in Zhangdu Lake, based on the subfossil assemblage of cladocerans from lake sediment. Planktonic cladocerans dominated the period ca. 1880s-1960s (Zone I), when the planktonic Bosmina sp. was the most dominant species. During this time, the abundance of total littoral cladocerans declined, when only a few species, including those that characteristically occupy both littoral and planktonic habitats, such as Chydorus sphaericus, were present (Fig. 4). However, a major hydrological shift occurred during the ca. 1960s-1980s (Zone II) following the construction of dams across the Yangtze River channels (ca. 1950s). Sediments deposited in the dam contained increasing numbers of remains of the littoral cladocerans, where some of the common species of cladocerans such as Acroperus harpae, Alona guttata, Alona rectangula, Chydorus sphaericus, Graptoleberis testudinaria, and Sida crystallina were gradually becoming dominant (Fig. 4). The abundance of littoral cladoceran species such as A. harpae, Alona intermedia, Alona affinis, Kurzia lattissima, Leydigia leydigi, A. guttata, Camptocercus rectirostris, and Disparalona rostrata increased fur- 


\section{Wetland response to water quality change in Liangzi Lake}

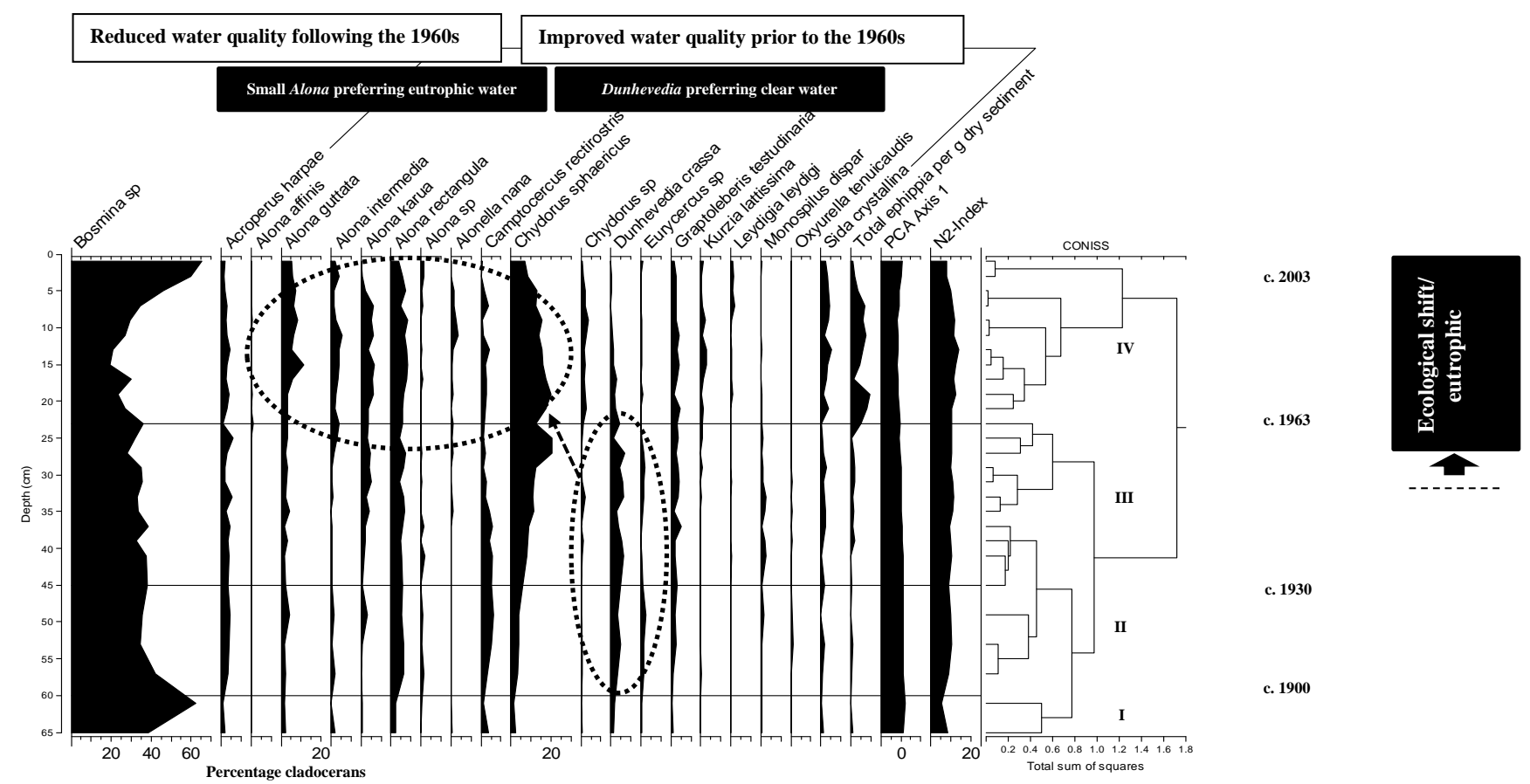

Figure 5. Composition (\%) and N2 diversity index of subfossil cladocerans in Liangzi Lake, and their response to past water quality change.

ther during the ca. 1990s-2000s (Zone III) indicating a significant change in both the ecologic and hydrologic systems. In addition, the concentration of the cladoceran resting eggs increased during this time (Fig. 4).

In the Zhangdu Lake, increased diversion of the water from the Yangtze River, during the 1960s-1970s because of the construction of dams, led to significant decline in the quantity of water and also the lake level. This resulted in a decrease of water depth around the lake margins, consequently providing suitable conditions for the increased growth of littoral vegetation and associated habitat for cladocerans. In response, the abundance of littoral cladocerans, including Alona affinis, Alona guttata, Alona intermedia, Camptocercus rectirostris, Kurzia latissima, and Leydigia leydigi, increased with high L:P ratios (Fig. 4). Smaller Alona such as A. guttata, A. rectangula, and $A$. intermedia showed a distinct presence during this time (Fig. 4).

\subsection{Liangzi Lake}

More than 20 cladoceran species were recorded from the Liangzi Lake. Bosmina sp., Acroperus harpae, Alona guttata, Alona rectangula, and Chydorus sphaericus were the most common taxa. The N2 diversity index of Liangzi Lake, prior to ca. 1900-1930 (the period of major hydrological disturbance), was lower than the period after the post-dam construction period in the Yangtze River (Fig. 5).
This hydrological condition in Yangtze River led to four distinct ecosystem changes in Liangzi Lake, as inferred by the subfossil assemblage of cladocerans retrieved from lake sediments. Prior to 1900 (Zone I), the total abundance of planktonic Bosmina was high. In the ca. 1900s-1920s (Zone II), the relative abundance of Bosmina began to decline, while the abundance of littoral species increased. The dominant species during this time were Acroperus harpae, Alona rectangula, Camptocercus rectirostris, and Dunhevedia crassa (Fig. 5). During the ca. 1930s-1950s (Zone III), the relative abundance of Bosmina was relatively constant, but the abundance of littoral species continued to increase. Four dominant species were found in this community; Alona rectangula, Chydorus sphaericus, Dunhevedia crassa, and Graptoleberis testudinaria. During the ca. 1960s-2000s, the period of major hydrological disturbances due to dam construction in the Yangtze, the total abundance of Bosmina increased, particularly in the early 2000s, and four species of littoral species, Alona guttata, Alona intermedia, Chydorus sphaericus, and Sida crystallina also became dominant throughout this period (Fig. 5). 


\section{Discussion}

\subsection{Shifts in hydrology and its implications for ecosystem functioning of wetlands within the Murray and Yangtze river wetlands}

Over the past century, impacts on the Murray and Yangtze rivers included the construction of irrigation dams, hydroelectric power plants, regulation works for navigation, land reclamation projects, and large-scale flood control measures (Maheshwari et al., 1995; Sun et al., 2012). As a result, vast areas of floodplain wetlands of both river systems have been drained and disconnected from the river. In some areas, this reduced hydrological connectivity has resulted in a flushing of organic matter and nutrients from the floodplains only during extreme floods, when the river retention capacity is the lowest. Therefore, organic matter from the floodplain system is not accessible to wetland organisms. With the loss of dynamically connected floodplains, the biogeochemical budget of the Murray and Yangtze river wetlands has changed significantly. Previous evidence strongly suggests that the climatic cycles of drought and flood have become extreme, triggering unusual responses of floodplain wetlands to the disturbance regime of these rivers (Zhang et al., 2012).

Wetlands losing hydrological connections with the river result in divergence of aquatic micro- and macro-invertebrate assemblages (Qin et al., 2009). The disruptions in the natural variability and connectivity of hydrological regimes, due to river-flow regulation, have consequently reduced ecological integrity, resulting in reduced invertebrate diversity (Sheldon et al., 2002). The downstream impacts of low flows in the River Murray were visible mainly following the construction of Hume Dam in 1936, but at present, average monthly and annual flows are still considerably lower than those of natural conditions in the past (Maheshwari et al., 1995). The study of natural flow regimes in the River Murray suggests that the strength of average annual floods (with an annual exceedance probability of $50 \%$ ) has reduced by over $50 \%$ at all stations. The effects of large floods with an average recurrence interval of 20 years or more, are, however, relatively low (Maheshwari et al., 1995). The number of low flows defined by a given annual nonexceedance probability, are higher under regulated conditions than under natural conditions (Maheshwari et al., 1995). The implications of these changes are not only for communities of native plants and animals in both riverine and floodplain environments but also for the long-term use of the riverine resources by humans (Maheshwari et al., 1995). Although the humans have consistently advanced the technology by compromising the low-flows environments for economic growth (Sivapalan et al., 2012), the exchange of particulate and dissolved organic matter, including suspended sediments, nutrients, and algal biomasses by rivers and their associated wetlands have substantially declined (Tockner et al., 1999). These nutrients are fundamental for the support of ecosystem structure and func- tion in riverine food webs (Bunn and Arthington, 2002). The current flow regimes also determine which physical habitats are available for all aquatic species that have evolved life history strategies primarily in direct response to natural flow regimes (Bedford, 1996).

Permanent inundation of wetlands occurred in many areas across the lower River Murray in response to the 1914 Commonwealth Act. This legislation enforced a requirement to manage the River Murray's water by the construction of locks, weirs, and water storage areas. Construction of the Mildura Weir (Lock 11), which began in August 1923, resulted in an increased water level in Kings Billabong by the time construction was completed in 1927. These long periods of water storage in Kings Billabong are thought to have increased stagnation, nutrient levels, and primary productivity, subsequently impacting the higher trophic levels around the billabong (Kattel et al., 2015). Some have argued that the high nutrient input in the river system, combined with relatively long water residence times in water storages, supports phytoplankton growth and a tendency towards eutrophication and poor water quality (e.g., Tockner et al., 1999; Chaparro et al., 2015).

In the Yangtze River, construction of many dams and water impoundments has significantly altered downstream hydrological regimes, which have directly affected the relationship between the Yangtze River and its river channels and floodplain wetlands, including the Zhangdu Lake (e.g., Yang et al., 2011a, b). The construction of dams throughout this catchment has caused changes in channel morphology and sedimentology, with a concomitant drastic decline in sediment transportation and severe channel erosion in connections to lakes. From the monitoring of stream cross sections, changes to river channels are evident, including the reduction of water level within wetlands (Yang et al., 2011a, b). These have inevitably induced alterations in inundation patterns of the wetlands, resulting in changes to ecosystem structure and function, which in turn have disturbed the habitats of biota (Maheshwari et al., 1995; Sun et al., 2012). As a consequence of a rapid expansion of human activity in the watershed during the 1960s, significant changes at the base of the food web in Zhangdu Lake have been observed in the subfossil composition of testate amoeba communities. For instance, the characteristic oligotrophic, lake-dwelling species (e.g., Difflugia biwae) have been replaced by eutrophic species (e.g., Difflugia oblonga) (Qin et al., 2009).

\subsection{Cladoceran-inferred responses to hydrological shifts in Murray and Yangtze river wetlands}

Cladoceran assemblages of three floodplain wetlands, Kings Billabong, Zhangdu Lake, and Liangzi Lake all have shown strong responses to human-mediated hydrological alterations in the Murray and Yangtze rivers over the past century. Although the $\mathrm{N} 2$ diversity index did not show a strong response to disturbance, the impact of river regulation and permanent 
inundation of Kings Billabong in the 1920s nonetheless revealed a decline in the density of littoral species.

As indicated earlier, Hill's N2 diversity index assumes that the number of species in an ecosystem is uniformly distributed (Hill, 1973). Following this advice, we assumed that the distribution of cladoceran species along the temporal scale of Murray and Yangtze river wetlands should also have been uniform. However, the N2 diversity index of cladocerans in Kings Billabong and Yangtze river wetlands was found to be nonuniform across our measurement period, and, in addition, they showed different trends in diversity. Following similar regulation and construction of dams in the two sites, the N2 diversity index decreased in Kings Billabong, whereas the N2 index in Yangtze River wetlands increased. These differences in responses of cladoceran diversity to regulation as shown by the N2 diversity index suggest some degree of variations in disturbances between the two river systems. Unlike the occurrence of more severe and frequent disturbances in Kings Billabong following the arrival of early European immigrants, the gradual or intermediate type of disturbances in Yangtze River wetlands could have resulted in the increased species diversity of cladocerans following regulation. With the historical perspective, the disturbances in Kings Billabong occurred within a very short timescale (e.g., years), while the disturbance in Yangtze River wetlands occurred over a longer timescale (e.g., decades), and could be characterized as intermediate frequencies of disturbance (Collins and Glenn, 1997). Indeed, records indicate that the early European immigrants in Australia transformed the landscapes quickly, which had severe impacts on Kings Billabong cladocerans. However, unlike Kings Billabong, the Yangtze River wetlands did not experience such a severe disturbance, and as the intermediate disturbance hypothesis model suggests, the diversity index increased following the disturbance (Townsend and Scarsbrook, 1997) indicating the intermediate frequencies of disturbance in cladoceran diversity of the Zhangdu and Liangzi lakes.

However, habitat stability determines the species and functional diversities of biota. In addition, the species diversity patterns are often context and system dependent (Biswas and Malik, 2010). For example, reduced water level, which results in increased light regime and higher growth of littoral vegetation, may provide stability of habitat for small Alona sp. in Yangtze River wetlands following the intermediate disturbance (ca. 1960s), and consequently this leads to an increased N2 diversity index (Figs. 4 and 5).

The species such as Dunhevedia crassa and Graptoleberis testudinaria, are adapted to submerged vegetation and their decline in abundance indicates a reduction of suitable habitat, such as decreased water quality. The increase in the abundance of lentic species, such as Bosmina meridionalis, demonstrates a switch from the prior ephemeral state to one of more or less constant inundation. Although drought had little or no impact on the water nutrient levels in Kings Billabong following regulation, by contrast, large-scale flood events such as in 1956, may have significantly increased nutrient input in the water column. The apparent result was to increase the population of Bosmina, as well as littoral species (e.g., A. guttata) that prefer enriched nutrient environments (Hofmann, 1996). Turbidity from suspended sediment during flood events also limits growth of submerged vegetation, due to a reduction of light penetration. By the early 2000s, planktonic B. meridionalis and littoral A. guttata and Biapertura longispina were the dominant species. The high density of cladoceran ephippia retrieved from the wetland sediment also indicates "stress" among the cladoceran community during the prevailing conditions of the post-regulation period in the River Murray system (Nevalainen et al., 2011). The low abundance of $D$. crassa following river regulation reflects the impact of river regulation on the aquatic ecosystem, with degraded water quality and reduced resilience in the wetland community. In shallow lakes, a consequence of human-induced actions is the tendency towards a regime shift, followed by poor ecological resilience (Folke et al., 2004). The loss of functional group species and consequent reduced species diversity may lead to a loss of whole trophic levels or "top-down effects" (Folke et al., 2004).

The Zhangdu Lake aquatic community responded to downstream water shortages in the river channel connecting to the lake, as revealed by low lake levels following the construction of dams and reservoirs for water conservation in the 1950s-1970s. Subsequent to river regulation during the 1950s, hydrological alterations of the river channel and changes to the water level of Zhangdu Lake, increased the growth of littoral plants. This also resulted in increased abundance of littoral cladoceran species, such as Acroperus harpae, Alona guttata, Alona rectangula, Chydorus sphaericus, Graptoleberis testudinaria, and Sida crystallina (Fig. 4). Although the abundance of littoral species in the lake indicated increased growth of submerged vegetation, the condition of the wetland ecosystem following regulation was poor. The clear water regime, present prior to regulation, gradually transformed to a eutrophic state following the construction of dams. Many small cladocerans recorded in Zhangdu Lake following the work of the 1950s, are typically associated with still (lotic) water, eutrophic and poor water quality conditions, and have been found in similar disturbed habitats elsewhere. For example, in Europe, cladoceran species such as A. harpae, C. sphaericus, and S. crystallina have a characteristic affiliation with lotic environments (Nevalainen, 2011). In addition, in Tibet, Chydorus sphaericus has been found to be adapted to wide range of environmental gradients, while Alona affinis and Acroperus harpae colonize dense aquatic macrophytes, and Graptolebris testudinaria and Eurycercus lamellatus are adapted to shallow littoral environments, with a preference for debris-rich substrates (Liping et al., 2005).

Eutrophication in Zhangdu Lake, due to hydrological changes of the wetland, was also indicated by the presence of testate amoeba (Qin et al., 2009). Our results strongly suggest that hydrological alterations of rivers and wetlands can 
result in eutrophication and lead to an increased abundance of smaller size littoral cladocerans. The low level of floods could reduce water level, increase telmatic plant growth, and decrease the redox condition of the wetland resulting in the variation in growth, metabolism, and reproduction of such cladocerans (Pawlowski et al., 2015). The shallow littoral environment provides habitats for different fish species, and may increase the predator-prey interactions (Pawlowski et al., 2015). Following regulation, the large number of cladoceran ephippia recorded in the sediment in Zhangdu Lake (which is found in the lower Yangtze), also indicates the decline in lake levels and the loss of lentic habitats, which leads to reduced feeding habitats and reproductive output or an increased ecological stress among the cladoceran community, particularly during the ca. 1990s-2000s. In Europe, increases in sedimentary resting eggs of cladocerans are reported to be associated with major environmental transitions; for example, climate change (such as Pleistocene-early Holocene), timing of strong predator-prey interactions (fish predation pressure), and increased human impact in the catchment (for example, unprecedented release of chemicals) (SarmajaKorjonen, 2003; Nevalainen et al., 2011).

The response of the subfossil assemblage of cladocerans in Liangzi Lake to hydrological change in the Yangtze River during the 1950s was difficult to establish. This could be due to the permanent inflow to this lake from the Yangtze River. The higher abundance of Bosmina prior to the 1900s indicate that the lake was kept at a certain water level, and much of the trophic materials contained in the surface water met the demands of planktonic cladocerans (Liping et al., 2005). However, the abundance of littoral species Alona rectangula, Chydorus sphaericus, Dunhevedia crassa, and Graptoleberis testudinaria during the 1950s are indicative of decreasing depth. During the 1990s-2000s, Liangzi Lake was impacted by intensive agriculture practices in the catchment and nutrient inputs into the wetland, as indicated by an increased abundance of planktonic Bosmina (Lipping et al., 2005). In 1992, the local government restricted aquaculture to the western part of the Liangzi Lake, since this activity was affecting water quality throughout the entire lake (Xie et al., 2001). This problem had been detected from ecological stress responses of cladocerans, as revealed by an increased density of resting eggs in the sediment, as well as an increased abundance of Bosmina and the chydorid species such as Alona guttata, Alona intermedia, Chydorus sphaericus, since these are all found in nutrient-rich environments (Sarmaja-Korjonen, 2003; Nevalainen et al., 2011).

All three of these wetlands appear to exhibit characteristic traits of hydrologically triggered ecosystem changes, as revealed by subfossil cladoceran assemblages, since each has tended to undergo regime shifts during recent decades. Furthermore, species richness in each is indicative of reduced water quality. Hydrology strongly drives the community composition of phyto- and zooplankton, relevant nutritional resources, and habitat characteristics, mainly via in- put of total nitrogen (TN) and total phosphorous (TP) from the eutrophic main channels during flood events (Van den B et al., 1994; Nevalainen, 2011). The phenomena observed in the dynamics of physical and biological assemblages, and the diversity of cladoceran zooplankton, in Kings Billabong and Zhangdu Lake, for example, have shown a tendency of existing in alternative stable states resulting from switching of ecosystems, irrespective of inundation (Kings Billabong) or dehydration (Zhangdu Lake).

The alternative "stable states phenomena" in shallow lakes and wetlands have been widely viewed as indicative of changes to resilience of ecosystems (Scheffer and Jeppesen, 2007). Such phenomena have shown the condition of wetlands to vary from a relatively good water quality, vegetationrich state to a poor, turbid water state, which is usually less desirable to society (Folke et al., 2004). Positive feedback associated with the condition of increased water quality, species richness and population dynamics of $D$. crassa in Kings Billabong prior to 1900 is characteristic of a resilient ecosystem (e.g., Suding et al., 2004). By contrast, an open water habitat, which may be characteristic of a longer flood duration following regulation, leads to negative feedback, which is turbid and less resilient (e.g., Suding et al., 2004). Similarly, in the Zhangdu and Liangzi lakes, an increased abundance of smaller, mud-dwelling cladoceran species such as small Alona sp. and Leydigia leydigi, as well as presence of other meso-eutrophic species, Chydorus and Bosmina following regulation, is indicative of increased eutrophication (Hofmann, 1996) caused by alteration of flow regime and dehydration of wetlands.

Long-term persistent human disturbances alter species diversity and have functional consequences in ecosystem processes (MacDougall et al., 2013), which may be observed via impact on ecological traits (Chapin III, 2000). The components of species diversity expressing certain traits include the number of species present (species richness), their relative abundances (species evenness), the particular species present (species composition), the interactions among species (nonadditive effects), and the temporal and spatial variation in these properties. The consequence to the environment as a result of cladoceran diversity change in the Murray and Yangtze river wetlands is difficult to predict, but in the longer term, poor functioning of the ecosystem due to reduction in diversity in Kings Billabong is expected. In the Yangtze River wetlands, the dominant species richness trait, for instance abundance of the small Alona sp. Group, can also lead to poor ecosystem functioning (e.g., Chapin III, 2000). This evidence strongly reflects the reduction in resilience and the limited capacity of these wetlands to support ecosystem services for the society in these increasingly regulated river basins. Further decline in ecohydrological conditions including the water quality, water quantity, fishery resources, and recreational amenities, due to cumulative stressors can lead to the collapse of ecosystem services, in which case society will no longer be benefitted (Falkenmark, 2003). 
The ecosystems of both Murray and Yangtze rivers are affected by a range of drivers. The cumulative stressors upon these wetlands are nutrient enrichments from agricultural catchments, heavy metal release from industries (mainly in Yangtze wetlands) and climate change (flooding and drought episodes). Increased nitrogen deposition has been reported to have a great effect on diversity and ecosystem functioning of wetlands, leading to collapse of food chains and ecosystems (Hooper et al., 2012). This collapse may lead to crises to higher trophic levels including the humans, with conflicting demands placed on natural resources and increasingly poor public health issues of the local community (Kattel et al., 2013). Such water problems in large river basins are due to increasingly interconnected multisector developments such as agriculture, energy, industry, transportation, and communication. Several authors (Walker et al., 1995; Kingsford et al., 2000; Fu et al., 2003) suggest that maintaining ecosystem health of wetlands associated with large river basins, requires a new paradigm in water management. Today, the wetlands of both the Murray and Yangtze river basins have faced greater challenges from hydrological modification, water shortage and eutrophication than at any time before (Yang et al., 2006; Shen, 2010; Gell and Reid, 2014), and there are growing concerns about the uncertainties of climate change and socioeconomic impacts on these river basins (Palmer et al., 2000). For example, due to rapid decline in water quality, biodiversity and ecological characters of the lower Yangtze River, this region has already been declared as the ecosystem of "lost resilience" (Zhang et al., 2015). A comprehensive synthesis by Varis and Vakkilainen (2001) suggests that following the 1970s, China's environmental pressures have surpassed the carrying capacity of the ecosystem, resulting in greater challenges for water resource management in the Yangtze and many other river basins. Similarly, a rapidly declining trend of biological diversity and ecosystem states of the River Murray basin has also been widely reported since the 1950s (Kingsford et al., 2000). For example, more than $80 \%$ of wetlands in the lower River Murray reaches (Australia) have undergone a significant decline in flow regimes and ecosystem health, due to rapid rates of sedimentation, turbidity, and loss of macrophytes (e.g., Mosley et al., 2012; Gell and Reid, 2014).

With increasing demand for water, food, fibre, minerals, and energy in the 21 st century, the water related pressures have degraded conditions of these natural resources further (e.g., Davis et al., 2015). It is claimed that solutions for water issues are not possible without a joint effort by the various stakeholders involved in understanding the complexity of water management in large river basins (e.g., Biswas, 2004). It has been envisaged that the current management program needs to be revitalized to resolve growing issues of wetland management and maintenance of associated ecosystem services, including the quantity and quality of water in both river basins.
The evidence of ecohydrological evolution of the Murray and Yangtze river wetlands inferred from the subfossil cladoceran assemblages and diversity (Figs. 3 and 4) suggests that both river basins have been profoundly impacted by socioeconomic developments over the past century. Many authors suggested that increased dialogues together with continuous learning are needed to achieve better water resource management practice (Holling, 1978; Jakeman and Letcher, 2003; Falkenmark, 2004; Macleod et al., 2007; Pahl-Wostl, 2007). For example, the time around the 1950s was a benchmark of change in flow regime and ecosystem of the Murray and Yangtze river wetlands. Following river regulation (post-1950s), both the quantity and quality of water in the Murray and Yangtze river wetlands began to alter, reaching a critically low level of flow, poor water quality and reduced ecosystem health by the 2000s. This condition of changes in flow regime in the River Murray basin was also reported by Maheshwari et al. (1995), where the average monthly and annual flows were considerably lower than those of natural conditions prior to regulation. This point of time in the River Murray basin was crucial for learning about the modification of natural hydraulic residence time that lead to changes in diversity and the associated ecosystem structure and functions of wetlands.

Construction of the Hume Dam in the 1930s in the River Murray, and several large dams including the Three Gorges Dam (TGD) since the 1950s in Yangtze River, has had long-lasting effects on downstream flow regimes, as well as wetland ecosystem structure and function (Pittock and Finlayson, 2011; Wu et al., 2003). The understanding of these benchmark evidences of human-induced ecohydrologic disturbances on these river basins have now been used for modeling the transitioning hydrology and critical level of threshold in the ecosystem of wetlands (Zweig and Kitchens, 2009; Wang et al., 2012). Humans have also consistently shaped the patterns of economic development altering the potential hydrological dynamics and feedbacks in the system through increased environmental consciousness and growing recognition of the interplays between hydrology and society (Sivapalan, 2012; Di Baldassarre et al., 2013). In many instances, progress has been made through the advancement in innovations in water resource management together with environmentally friendly infrastructure development that have contributed to balanced water allocations across the households, agriculture, industry, and environment (Poff et al., 2003; Biswas, 2004; Lee and Ancev, 2009; Jiang, 2009; Yu et al., 2009; Fu et al., 2010; Grafton et al., 2013).

In addition, the making the linkages between the restoration requirements suggested by science and the needs of society have become increasingly useful for management decisions of the large river basins (Poff et al., 2003; Pittock and Finlayson, 2011; Liu et al., 2015). The community engagement with all aspects of ecohydrology, including both structural developments (such as hydropower dams) and nonstructural infrastructure programs (typified by awareness) ap- 
proached for adaptation to change as well as water savings, has become highly successful (Shen, 2010). Such engagement has enhanced wetland resilience with improved water quality and quantity, including ecosystem functions, consequently assisting the basin-wide management of food and water security issues (Carpenter et al., 2009; Vörösmarty et al., 2010; Liu et al., 2015). For example, the WWF-supported partnership program, together with government agencies and local communities, was highly successful for improving water resources, both quantitatively and qualitatively, in the Yangtze River basin. Under this type of management program, and in partnership with local people, the three Yangtze lakes (Zhangdu, Hong, and Tian-e-zhou), which were disconnected from the main channel during the 1950s-1970s, have now been recharged by opening of sluice gates (Yu et al., 2009). The recharging of Zhangdu Lake has not only enhanced resilience of the lake environment to climate change and but also livelihoods of the local people (Yu et al., 2009). Recently, the role of community participation in water resource management has also been reported significant in some wetlands of the Murray-Darling Basin. For example, the living Murray project initiated by the Murray-Darling Basin Authority with the view of increased indigenous community engagement, has led to improvements in the ecological health of the Barmah-Millewa floodplain wetlands supporting large bird breeding events (MDBA, 2014). This kind of success has also been revealed by the coupled sociohydrologic models showing strong association between the trajectory of human-water coevolution and associated goods and services in the Murrumbidgee River basin (one of subbasins of the River Murray) (Sivapalan et al., 2012; Kandasamy et al., 2014, van Emmerik et al., 2014).

\section{Conclusions}

Evidence from subfossil assemblages of cladocerans over the past few decades from all three wetlands, Kings Billabong, Zhangdu Lake, and Liangzi Lake, suggest that river regulation by humans in the Murray (Australia) and Yangtze (China) rivers have significantly altered natural flows, including the hydrology and ecology of these wetlands. The response of subfossil cladoceran assemblages was evident via both prolonged flooding (inundation) and dehydration (abstraction) of water in the Murray and Yangtze rivers, respectively. Other factors, such as land use, socioeconomic developments, and rapid climate change, particularly over the past 30-40 years, may have exacerbated the hydrological and ecological processes further. The conditions of wetlands following large-scale disturbances, such as widespread river regulation and construction of dams and reservoirs, have shown tendency to trigger wetland ecosystem switches, and highlights the urgent need for effective restoration measures to improve ecosystem services, through better management of quantity and quality of water. Evidence based on strong scientific research, development of efficient infrastructure, and people's participation together enhance resilience of the Murray and Yangtze river wetlands and help resolve longterm, basin-wide water and food security issues.

Acknowledgements. This project was supported by a number of grants awarded to authors including the Chinese Academy of Sciences (CAS-President's International Fellowship Initiative for Visiting Professor to Giri R. Kattel), the National Natural Science Foundation of China (no. 41472314 and no. 41102105 to Xuhui Dong, and Xiangdong Yang and Giri R. Kattel), the Australian Institute of Nuclear Science and Engineering (no. AINSEGRA11087 to ) and the Australia-China Science and Research Fund (ACSRF to Giri R. Kattel). The State Key Laboratory of the Nanjing Institute of Geography and Limnology Chinese Academy of Sciences (NIGLAS); Australian Nuclear Science and Technology Organisation (ANSTO); the Collaborative Research Network (CRN); and the Faculty of Science and Technology of Federation University Australia (FedUni) assisted collection of samples from the field and analyses at the respective laboratories. A part of this research was written at the Environmental Hydrology and Water Resources Unit of the Department of Infrastructure Engineering, University of Melbourne, Australia. This paper was presented in Australia-China Wetland Network Research Partnership Symposium (24 March 2014) in Nanjing, China. We would like to thank the HESS Editor Giuliano Di Baldassarre, two anonymous reviewers, and the third reviewer, Tim van Emmerik from Delft University of Technology (the Netherlands) for their highly constructive comments on the manuscript. Finally, Jim Sillitoe is kindly acknowledged for his editorial support.

Edited by: G. Di Baldassarre

\section{References}

Appleby, P. G.: Chronostratigraphic techniques in recent sediments, in: Tracking Environmental Change Using Lake Sediments, Volume 1: Basin Analysis, Coring and Chronological Techniques, edited by: Last, W. M. and Smol, J. P., 171-203, Kluwer Academic Publishers, Dordrecht, 2001.

Bedford, B.: The need to define hydrologic equivalence at the landscape scale for freshwater wetland mitigation, Ecol. Appl., 6, 57$68,1996$.

Biswas, A. K.: Integrated water resources management: a reassessment, Water Int., 29, 248-256, 2004.

Biswas, S. R. and Mallik, A. U.: Disturbance effects on species diversity and functional diversity in riparian and upland plant communities, Ecology, 28-35, 2010.

Bunn, S. E. and Arthington, A. H.: Basic principles and ecological consequences of altered flow regimes for aquatic biodiversity, Environ. Manage., 30, 492-507, 2002.

Cai, W. and Cowan, T.: Evidence of impacts from rising temperature on inflows to the Murray-Darling Basin, Geophys. Res. Lett., 35, L07701, doi:10.1029/2008GL033390, 2008.

Carpenter, S. R., Mooney, H. A., Agard, J., Capistrano, D., DeFries, R. S., Diaz, S., Dietz, T., Duraiappah, A. K., Oteng-Yeboah, A., Pereira, H. M., Perrings, C., Reid, W. V., Sarukhan, J., Scholes, 
R. J., and Whyte, A.: Science for managing ecosystem services: beyond the millennium ecosystem assessment, P. Natl. Acad. Sci. USA, 106, 1305-1312, 2009.

Chaparro, G., Fontanarrosa, M. S., Cataldo, D., and O'Farrel, I.: Hydrology driven factors might weaken fish predation effects on zooplankton structure in a vegetated warm temperate floodplain lake, Hydrobiologia, 752, 187-202, 2015.

Chapin III, F. S., Zavaleta, E. S., Eviner, V. T., Naylor, R. L., Vitousek, P. M., Reynolds, H. L., Hooper, D. U., Lavorel, S., Sala, O. E., Hobbie, S. E., Mack, M. C., and Diaz, S.: Consequences of changing biodiversity, Nature, 405, 234-242, 2000.

Chen, X., Yang, X., Dong, X., and Liu, Q.: Nutrient dynamics linked to hydrological condition and anthropogenic nutrient loading in Chaohu Lake (southeast China), Hydrobiologia, 661, 223 234, 2011

Collins, S. L. and Glenn, S. M.: Intermediate disturbance and its relationship to within-and between-patch dynamics, NZ J. Ecol., 21, 103-110, 1997.

Davis, J., O'Grady, A. P., Dale, A., Arthington, A. H., Gell, P. A., Driver, P. D., Bond, N., Casanova, M., Finlayson, M., Watts, R. J., Capon, S. J., Nagelkerken, I., Tingley, R., Fry, B., Page, T. J., and Specht, A.: When trends intersect: The challenge of protecting freshwater ecosystems under multiple land use and hydrological intensification scenarios, Sci. Total Environ., 534, 65-78, doi:10.1016/jscitotenv.2015.03.127, 2015.

Di Baldassarre, G., Viglione, A., Carr, G., Kuil, L., Salinas, J. L., and Blöschl, G.: Socio-hydrology: conceptualising humanflood interactions, Hydrol. Earth Syst. Sci., 17, 3295-3303, doi:10.5194/hess-17-3295-2013, 2013.

Dong, X., Anderson, N. J., Yang, X., Chen, X., and Shen, J.: Carbon burial by shallow lakes in the Yangtze floodplain and its relevance to regional carbon sequestration, Global Change Biol., 18, 2205-2217, 2012.

Dumbrell, A. J., Clark, E. J., Frost, G. A., Randell, T. E., Pitchford, J. W., and Hill, J. K.: Changes in species diversity following habitat disturbance are dependent on spatial scale: theoretical and empirical evidence, J. Appl. Ecol., 45, 1531-1539. 2008.

Ellis, I. and Meredith, S.: Aquatic fauna survey of wetlands 351 and 491 near Wentworth, Southwest NSW, technical report, Murray Darling Freshwater Research Centre, Mildura, Victoria, Australia, 2005.

Falkenmark, M.: Freshwater as shared between society and ecosystems: from divided approaches to integrated challenges, Philos. Trans. R. Soc. Lnd., 358, 2037-2049, 2003.

Falkenmark, M.: Towards integrated catchment management: opening the paradigm locks between hydrology, ecology and policymaking, Int. J. Water Resour. Develop., 20, 27-281, 2004.

Folke, C., Carpenter, S., Walker, B. W., Scheffer, M., Elmqvist, T., Gunderson, L., and Holling, C. S.: Regime shifts, resilience, and biodiversity in ecosystem management, Annu. Rev. Ecol. Evol. Syst., 35, 557-581, 2004.

Frey, D. G.: Cladocera analysis, in: Handbook of Holocene Palaeoecology and Palaeohydrology, edited by: Berglund, B. E., John Wiley \& Sons Ltd., Chichester, 667-692, 1986.

Fu, B. J., Wu, B. F., Lu, Y. H., Xu, Z. H., Cao, J. H., Niu, D., Yang, G. S., and Zhou, Y. M.: Three Gorges Project: Efforts and challenges for the environment, Prog. Phys. Geogr., 1-14, 2010.
Fu, C., Wu, J., Chen, J., Wu, Q., and Lei, G.: Freshwater fish biodiversity in the Yangtze River basin of China: patterns, threats and conservation, Biodivers. Conserv., 12, 1649-1650, 2003.

Gell, P. A. and Reid, M.: Assessing change in floodplain wetland condition in the Murray Darling Basin, Australia, Anthropocene, 8, 39-45, 2014.

Gell, P. A., Fluin, J., Tibby, J., Hancock, G., Harrison, J., Zawadzki, A., Haynes, D., Khanum, S., Little, F., and Walsh, B.: Anthropogenic acceleration of sediment accretion in lowland floodplain wetlands, Murray Darling Basin, Australia, Geomorphology, 108, 122-126, 2009.

Gippel, C. J. and Blackham, D.: Review of Environmental Impacts of Flow Regulation and Other Water Resource Developments in the River Murray and Lower Darling River System: Includes Glossary of Terms: Final Report to Murray Darling Basin Commission, Murray Darling Basin Commission, 2002.

Grafton, R. Q., Pittock, J., Davis, R., Williams, J., Fu, G., Warburton, M., Udall, B., McKenzie, R., Yu, X., Che, N., Connel, D., Jiang, Q., Kompas, T., Lynch, A., Norris, R., Possingham, H., and Auiggin, J.: Global insights into water resources, climate change and governance, Nature Clim. Change, 3, 315-321, 2013.

Grimm, N.: Nitrogen dynamics during succession in a desert stream, Ecology, 68, 1157-1170, 1987.

Hill, M. O.: Diversity and evenness: A unifying notation and its consequences, Ecology, 54, 427-432, 1973.

Hill, M. O. and Gauch Jr., H. G.: Detrended correspondence analysis: an improved ordination technique, Vegetatio, 42, 47-58, 1980.

Hofmann, W.: Empirical relationships between cladoceran fauna and trophic state in thirteen northern German lakes: analysis of surficial sediments, Hydrobiologia, 318, 195-201, 1996.

Holling, C. S.: Adaptive environmental assessment and management, John Willey and Sons, Chichester, xviii+377, 1978.

Hooper, D. U., Adair, E. C., Cardinale, B. J., Byrnes, J. E. K., Hungate, B. A., Matulich, K. L., Gonzalez, A., Duffy, J. E., Gamfeldt, L., and O'Connor, M. I.: A global synthesis reveals biodiversity loss as a major driver of ecosystem change, Nature, 486, 105$108,2012$.

Jakeman, A. J. and Letcher, R. A.: Integrated assessment and modelling: features, principles and examples for catchment management, Environ. Model. Softw., 18, 491-501, 2003.

Jeppesen, E. and Sammalkorpi, I.: Lakes, in: Handbook of Ecological Restoration, vol. 2. Restoration in Practice, edited by: Perrow, M. R. and Davy, A. J., Cambridge University Press, Cambridge, 618 pp., 2002.

Jeppesen, E., Leavitt, P., De Meester, L., and Jensen, J. P.: Functional ecology and palaeolimnology: using cladoceran remains to reconstruct anthropogenic impact, Trends Ecol. Evol., 16, 191198, 2001.

Jiang, Y.: China's water scarcity, J. Environ. Manage., 90, 3185 3196, 2009.

Junk, W. J., Bayley, P. B., and Sparks, R. E.: The flood pulse concept in river continuum systems, in: Proceedings of International Large Rivers Symposium, edited by: Dodge, D. P., Canadian Special Publication of Fisheries and Aquatic Sciences, 106, 89109, 1989.

Kandasamy, J., Sounthararajah, D., Sivabalan, P., Chanan, A., Vigneswaran, S., and Sivapalan, M.: Socio-hydrologic drivers of the pendulum swing between agricultural development and en- 
vironmental health: a case study from Murrumbidgee River basin, Australia, Hydrol. Earth Syst. Sci., 18, 1027-1041, doi:10.5194/hess-18-1027-2014, 2014.

Kattel, G. R., Battarbee, R. W., Mackay, A. W., and Birks, H. J. B.: Recent ecological change in remote mountain loch: an evaluation of cladocera-based temperature transfer function, Palaeogeogr. Palaeoecol. Palaeooceanogr., 259, 51-76, 2008.

Kattel, G. R., Elkadi, H., and Meikle, H.: Developing a complementary framework for urban ecology, Urban Forest. Urban Green., 12, 498-508, 2013.

Kattel, G. R., Gell, P., Perga, M.-E., Jeppesen, E., Grundell, R., Weller, S., Zawadzki, A., and Barry, L.: Tracking a century of change in trophic structure and dynamics in a floodplain wetland: integrating palaeoecological and palaeoisotopic evidence, Freshw. Biol., 60, 711-723, 2015.

Kingsford, R. T.: Ecological impacts of dams, water diversions and river management on floodplain wetlands in Australia, Austral. Ecol., 25, 109-127, 2000.

Lake, P. S., Palmer, M. A., Bird, P., Cole, J., Covich, A. P., Dahm, C., Gibert, G., Goedkoop, W., Martens, K., and Verhoeven, J.: Global change and the biodiversity of the freshwater ecosystems. Impacts on linkages between above sediment and sediment biota, Bioscience, 50, 1099-1107, 2000.

Lee, L. Y.-T. and Ancev, T.: Two decades of Murray-Darling Water Management: A River of Funding, a Trickle of Achievement, J. Pol. Anal. Ref., 16, 5-23, 2009.

Liping, Z., Junbo, W., and Anton, B.: A study on environmental changes based upon cladoceran assemblages from the core sediments in Chen Co, southern Tibet, Chinese Sci. Bull., 50, 13861394, 2005.

Liu, J., Kattel, G., Arp, H. P. H., and Yang, H.: Towards threshold-based management of freshwater ecosystems in the context of climate change, Ecol. Model., 318, 265-274, doi:10.1016/j.ecolmodel.2014.09.010, 2015.

Liu, Q., Yang, X., Anderson, N. J., Liu, E., and Dong, X.: Diatom ecological response to altered hydrological forcing of a shallow lake on the Yangtze floodplain, SE China, Ecohydrology, 5, 316325, 2012.

Lloyd, L.: Malee Catchment Authority: Kings Billabong Operating Plan, Lloyd Environ., Victoria, Australia, 69 pp., 2012.

Macleod, C. J. A., Scholdfield, D., and Haygrath, P. M.: Irrigation for sustainable catchment management, Sci. Total Environ., 373, 591-602, 2007.

MacDougall, A. S., McCann, K. S., Gellner, G., and Turkington, R.: Diversity loss with persistent human disturbance increases vulnerability to ecosystem collapse, Nature, 494, 86-89, 2013.

Maddock, I., Thoms, M., Jonson, K., Dyer, F., and Lintermans, M.: Identifying the influence of channel morphology on physical habitat availability for native fish: application to the twospined backfish (Gadopsis bispinosus) in the Cotter River, Australia, Marine Freshw. Res., 55, 173-184, 2004.

Maheshwari, B. L., Walkers, K. F., and McMahon, T. A.: Effects of regulation on the flow regime of the river Murray, Australia, Regul. River., 10, 15-38, 1995.

McGowan, S., Leavitt, P., Hall, R, Wolfe, B. B., Edwards. T. D., Karst-Riddoch, T. K., and Vardy, S. R.: Interdecadal declines in flood frequency increase primary production in lakes of a northern river delta, Global Change Biol., 17, 1212-1224, 2011.
MDBA: The Living Murray 2013-14 Environmental Watering Report, MDBA, Canberra, 2014.

Mosley, L. M., Zammit, B., Leyden, E., Heneker, T. M., Hipsey, M. R., Skinner, D., and Aldridge, K. T.: The impact of extreme low flows on the water quality of the lower Murray River and lakes (South Australia), Water Resour. Manage., 26, 3923-3946, 2012.

Nevalainen, L.: Intra-lake heterogeneity of sedimentary cladoceran (crustacean) assemblages forced by local hydrology, Hydrobiologia, 676, 9-22, 2011.

Nevalainen, L., Luoto, T., Levine, S., and Manca, M.: Paleolimnological evidence for increased sexual reproduction in chydorids (Chydoridae, Cladocera) under environmental stress, J. Limnol., 70, 255-262, 2011.

Nilsson, C. and Berggren, K.: Alterations of Riparian Ecosystems Caused by River Regulation, Bioscience, 50, 783-792, 2000.

Pahl-Wostl, C.: Transitions towards adaptive management of water facing climate and global change, Water Resour. Manage., 21, 49-62, 2007.

Palmer, M. A., Liermann, C. A. R., Nilsson, C., Flörke, M., Alcamo, J., Lake, P. S., and Bond, N.: Climate change and the world's river basins: anticipating management options, Front. Ecol. Environ., 6, 81-89, 2008.

Parks Victoria: The Management Plan for Kings Billabong Wildlife Reserve, Parks Victoria, Melbourne, 62 pp., 2008.

Pawlowski, D., Kowalewski, G., Milecka, K., Plóciennik, M., Woszczyk, M., Zieliński, T., Okupny, D., Wlowdarski, W., and Forysiak, J.: A reconstruction of the palaeohydrological conditions of a flood plain: a multi-proxy study from the Grabia River valley mire, central Poland, Boreas, 44, 553-562, doi:10.1111/bor.12115, 2015.

Pittock, J. and Finlayson, C. M.: Australia's Murray-Darling Basin freshwater ecosystem conservation options in an area of climate change, Marine Freshw. Res., 62, 232-243, 2011.

Poff, N. L, Allan J. D., Palmer, M. A., Hart, D. D., Richter, B. D., Arthington, A. H., Rogers, K. H., Meyer, J. H., and Stanford, J. A.: River flows and water wars: emerging science for environmental decision making, Front. Ecol. Environ., 6, 298-306, 2003.

Power, M. E., Dietrich, W. E., and Finlay, J. C.: Dams and downstream aquatic biodiversity: potential food web consequences of hydrologic and geomorphic change, Environ. Manage., 20, 887895, 1996.

Puckridge, J. T., Sheldon, F., Walker, K. F., and Boulton, A.: Flow variability and the ecology of the large rivers, Marine Freshw. Res., 49, 55-72, 1998.

Qin, Y., Booth, R. K., Gu, Y., Wang, Y., and Xie, S.: Testate amoebae as indicators of 20th century environmental change in Lake Zhangdu, China, Fundamental and Applied Limnology/Archiv für Hydrobiologie, 175, 29-38, 2009.

Reid, M., Sayer, C. D., Kershaw, A. P., and Heijnis, H.: Palaeolimnological evidence for submerged plant loss in a floodplain lake associated with accelerated catchment soil erosion (Murray River, Australia), J. Paleolimnol., 38, 191-208, 2007.

Richter, B. D., Mathews, R., Harrison, D. L., and Wigington, R.: Ecologically sustainable water management: managing river flows for ecological integrity, Ecol. Appl., 13, 206-224, 2003.

Sarmaja-Korjonen, K.: Chydorid ephippia as indicators of environmental change biostratigraphical evidence from two lakes in southern Finland, The Holocene, 13, 691-700, 2003. 
Scheffer, M. and Jeppesen, E.: Regime shifts in shallow lakes, Ecosystems, 10, 1-3, 2007.

Scheffer, M., Hosper, S. H., Meijer, M. L., and Moss, B.: Alternative equilibria in shallow lakes, Trends Ecol. Evol., 8, 275-279, 1993.

Sheldon, F., Boulton, A. J., and Puckridge, J. T.: Conservation value of variable connectivity: aquatic invertebrate assemblages of channel and floodplain habitats of a central Australian aridzone river, Cooper Creek, Biol. Conserv., 103, 13-31, 2002.

Shen, D.: Climate change and water resources: evidence and estimate in China, Clim. Change Water Resour., 98, 1063-1068, 2010.

Shiel, R. J. and Dickson, A.: Cladocera recorded from Australia, T. Roy. Soc. South Austr., 119, 29-40, 1995.

Sivapalan, M., Savenije, H. H. G., and Blöschl, G.: Sociohydrology: A new science of people and water, Hydrol. Process, 26, 1270-1276, 2012.

Suding, K. N., Gross, K. L., and Houseman, G. R.: Alternative states and positive feedbacks in restoration ecology, Trends Ecol. Evol., 19, 46-53, 2004.

Sun, Z., Huang, Q., Opp, C., Hennig, T., and Marold, U.: Impacts and Implications of Major Changes Caused by the Three Gorges Dam in the Middle Reaches of the Yangtze River, China, Water Resour. Manage., 26, 3367-3378, 2012.

Szeroczyńska, K. and Sarmaja-Korjonen, K.: Atlas of Subfossil Cladocera from Central and Northern Europe, Friends of the Lower Vistula Society, Poland, 2007.

ter Braak, C. J. F. and Verdonschot, P. F. M.: Canonical correspondence analysis and related multivariate methods in aquatic ecology, Aqua. Sci., 57, 255-289, 1995.

Thorp, J. H. and Delong, M. D.: The riverine productivity model: an heuristic view of carbon sources and organic processes in large river ecosystem, Oikos, 70, 305-308, 1994.

Tockner, K., Pennnetzdorfer, D., Feiner, N., Schiemer, F., and Ward, J. V.: Hydrological connectivity, and the exchange of organic matter and nutrients in a dynamic river-floodplain system (Danube, Austria), Freshw. Biol., 41, 521-535, 1999.

Townsend, C. R. and Scarsbrook, M. R.: The intermediate disturbance hypothesis, refugia, and biodiversity in streams, Limnol. Oceanogr., 42, 938-949, 1997.

Van den Brink, F. W. B., Van Katwijk, M. M., and Van der Velde, G.: Impact of hydrology on phyto- and zooplankton community composition in floodplain lakes along the Lower Rhine and Meuse, J. Plankton Res., 16, 351-373, 1994.

van Emmerik, T. H. M., Li, Z., Sivapalan, M., Pande, S., Kandasamy, J., Savenije, H. H. G., Chanan, A., and Vigneswaran, S.: Socio-hydrologic modeling to understand and mediate the competition for water between agriculture development and environmental health: Murrumbidgee River basin, Australia, Hydrol. Earth Syst. Sci., 18, 4239-4259, doi:10.5194/hess-18-42392014, 2014.

Varis, O. and Vakkilainen, P.: China's 8 challenges to water resource management in the first quarter of the 21 st century, Geomorphology, 93, 93-104, 2001.

Vörösmarty, C. J., McIntyre, P. B., Gessner, M. O., Dudgeon, D., Prusevich, A. Green, P., Glidden, S., Bunn, S. E., Sullivan, C. A., Liermann, C. R., and Davies, P. M.: Global threats to human water security and river biodiversity, Nature, 467, 555-561, 2010.

Walker, K. F.: A review of the ecological effects of the river regulation in Australia, Hydrobiologia, 125, 111-129, 1985.
Walker, K. F., Scheldon, F., and Puckridge, J. T.: A perspective on dryland river ecosystems, Regul. River. Manage., 11, 85-104, 1995.

Wang, L. M., Hu, H. J., and Wang, D.: Ecological impacts of disconnection from the Yangtze River on fish resources in Zhangdu Lake, Resources and Environment in the Yangtze Valley, 14, 287-292, 2005.

Wang, R., Dearing, J. A., Langdon, P. G., Zhang, E., Yang, X., Vasilis, D., and Scheffer, M.: Flickering gives early warning signals of a critical transition to a eutrophic lake state, Nature, 492 , 419-422, 2012.

Wu, J., Huang, J., Han, X., Xie, Z., and Gao, X.: Three Gorges DamExperiment in habitat fragementation?, Science, 300, 12391240, 2003.

Xie, S., Cui, Y., and Li, Z.: Small fish communities in two regions of the Liangzi Lake, China, with or without submersed macrophytes, J. Appl. Icthyol., 17, 89-92, 2001.

Yang, S. L., Liu, Z., Dai, S. B., Gao, Z. X., Zhang, J., Wang, H. J., Luo, X. X., Wu, C. S., and Zhang, Z.: Temporal variations in water resources in the Yangtze River (Changjiang) over the Industrial Period based on reconstruction of missing monthly discharges, Water Resour. Res., 46, W10516, doi:10.1029/2009WR008589, 2010.

Yang, S. L., Milliman, J. D., Li, P., and Xu, K.: 50,000 dams later: erosion of the Yangtze River and its delta, Global Planet. Change, 75, 14-20, 2011a.

Yang, S. L., Milliman, J. D., Li, P., and Xu, K.: 50,000 dams later: erosion of the Yangtze River and its delta, Global Planet. Change, 75, 14-20, 2011b.

Yang, X., Ji, S., Dong, X., Liu, E., and Wang, S.: Historical trophic evolutions and their ecological responses from shallow lakes in the middle and lower reaches of the Yangtze River: Case studies on Longgan Lake and Taibai Lake, Sci. China D, 49, Supp. I, 51-61, 2006.

Yang, X., Anderson, N. J., Dong, X., and Shen, J.: Surface sediment diatom assemblages and epilimnetic total phosphorus in large, shallow lakes of the Yangtze floodplain: their relationships and implications for assessing long-term eutrophication, Freshw. Biol., 53, 1273-1290, 2008.

Yin, H. and Li, C.: Human impact on floods and flood disasters on the Yangtze River, Geomorphology, 41, 105-109, 2001.

Yu, X., Jiang, L., Li, L., Wang, J., Wang, L., Lei, G., and Pittock, J.: Freshwater management and climate change adaptation: Experiences from the central Yangtze in China, Clim. Develop., 1, 241-248, 2009.

Zedler, J. B. and Kercher, S.: Wetland resources: status, trends, ecosystem services, and restorability, Annu Rev. Env. Resour., 30, 39-74, 2005.

Zhang, E., Cao, Y., Langdon, P., Jones, R., Yang, X., and Shen, J.: Alternate trajectories in historic trophic change from two lakes in the same catchment, Huayang Basin, middle reach of Yangtze River, China, J. Paleolimnol., 48, 367-381, 2012.

Zhang, K., Dearing, J. A., Dawson, T. P., Dong, X., Yang, X., and Zhang, W.: Poverty alleviation strategies in eastern China lead to critical ecological dynamics, Sci. Total Environ., 506-507, 164181, 2015.

Zhang, J., Zhang, Z. F., Liu, S. M., Wu, Y., Xiong, H., and Chen, H. T.: Human impacts on the large world rivers: Would the 
Changjiang (Yangtze River) be an illustration?, Global Biogeochem. Cy., 13, 1099-1105, 1999.

Zhang, Q., Dong, X., Yao, M., Chen, S., and Yang, X.: Environmental changes in response to altered hydrological connectivity with Yangtze River in Lake Zhangdu (Hubei Province) over the past 200 years, J. Lake Sci., 25, 463-470, 2013.
Zhu, L., Wang, J., and Brancelj, A.: A study on environmental changes based upon cladoceran assemblages from the core sediments in Chen Co, southern Tibet, Chinese Sci. Bull., 50, 13861394, 2005.

Zweig, C. L. and Kitchens, W. M.: Multi-state succession in wetlands: a novel use of state and transition models, Ecology, 90, 1900-1909, 2009. 